\title{
Current status and distribution of birds of prey in the Canary Islands
}

\author{
CÉSAR-JAVIER PALACIOS
}

\section{Summary}

I analyse recent trends in the status and distribution of breeding birds of prey in the Canary Islands (Spain). Populations of Barbary Falcon Falco peregrinus pelegrinoides, Eleonora's Falcon Falco eleonorae, Sparrowhawk Accipiter nisus granti, Buzzard Buteo buteo insularum and Osprey Pandion haliaetus recovered throughout the 1990s. Egyptian Vulture Neophron percnopterus majorensis continues to be seriously threatened, with a total population of only around 130 birds. There is a lack of information on status of nocturnal birds of prey, especially of the Canary subspecies of Barn Owl Tyto alba gracilirostris, whose numbers seem to have decreased. Genetic studies should be carried out to clarify the taxonomic status of the birds of prey of the Canary Islands.

\section{Introduction}

The Atlantic archipelago of the Canary Islands is situated $100 \mathrm{~km}$ from the coast of Africa, forming part of the Macaronesian region. It comprises seven islands and a series of islets totalling $7,447 \mathrm{~km}^{2}$ (Fernández-Palacios and Días 2001). Seven species of diurnal birds of prey and two nocturnal species breed on the islands, with a total of 11 subspecies with high conservation interest, five of which are endemic to the Canary Islands and two to the Macaronesian region.

The first detailed study on the status and distribution of birds of prey of the Canaries was made in $1987 / 8$ by the Tenerife Museum of Natural Sciences (Delgado et al. 1988), but it was only partially published (see Delgado et al. 1990). This work verified that the populations of most raptor species decreased during the twentieth century. It also confirmed the extinction of Red Kite Milvus milvus throughout the archipelago, of Egyptian Vulture Neophron percnopterus in Tenerife and Gran Canaria, and of Buzzard Buteo buteo insularum in Lanzarote, as well as the precarious situation of populations of Barbary Falcon Falco peregrinus pelegrinoides. It also described increases in Kestrel Falco tinnunculus and Longeared Owl Asio otus canariensis populations. As far as threats and other aspects of conservation are concerned, Carrillo and Delgado (1991) is as relevant today as it was then.

Existing information on Canarian birds of prey is unequal and scattered. Initially it was limited to reports of scientific expeditions made at the end of the nineteenth and the first half of the twentieth century. The information gathered was formerly either unpublished (internal reports for local governments) or published in Spanish in local journals with low diffusion among researchers. These works are principally censuses, with little information on genetics, ecology, 
conservation or biology of most of these species. Only in the case of nocturnal birds of prey and the most abundant diurnal species (Kestrel) is there a little information. In this paper I review the status of Canarian birds of prey, considering previously published information, and make some estimations of their current status and distribution. I have based my research on both unpublished studies and my own data, which are summarised in Table 1.

\section{Canary Egyptian Vulture Neophron percnopterus majorensis}

The Canary population of Egyptian Vulture has traditionally been considered as belonging to the nominate subspecies Neophron p. percnopterus, but a recent study proposed its separation into a new subspecies, ssp. majorensis, on the basis of morphological and genetic differences (Donázar et al. 2002a). The population is now reduced to around 25 breeding pairs, mainly on the island of Fuerteventura, but also on Lanzarote and Alegranza. This reduced number, totalling fewer than 130 individuals (55-60 adults), together with a clearly negative trend, makes it currently one of the most threatened birds of prey in both Spain and the European Union (Donázar et al. 2002b). Fuerteventura holds $93 \%$ of the reproductive

Table 1. Evolution of breeding populations of birds of prey in the Canaries (see text for references).

\begin{tabular}{|c|c|c|c|c|c|}
\hline & \multicolumn{2}{|c|}{$\begin{array}{l}\text { Breeding population } \\
\text { (pairs) }\end{array}$} & \multirow[t]{2}{*}{ Red List } & \multirow[t]{2}{*}{ Trend } & \multirow[t]{2}{*}{ Threats } \\
\hline & 1988 & 2001 & & & \\
\hline $\begin{array}{l}\text { Neophron percnopterus } \\
\text { majorensis }\end{array}$ & $31-37$ & 29 & CR & Decreasing & Powerlines, poisons, lead \\
\hline Accipiter nisus granti & 170 & $200-225$ & VU & Increasing & Destruction of habitat \\
\hline Buteo buteo insularum & $425-450$ & 500 & NT & Increasing & Poisons, illegal hunting \\
\hline Pandion haliaetus & 12 & $15-20$ & $\mathrm{CR}$ & Increasing & $\begin{array}{l}\text { Destruction of habitat } \\
\text { human disturbance }\end{array}$ \\
\hline $\begin{array}{l}\text { Falco tinnunculus } \\
\text { canariensis }\end{array}$ & $?$ & $4, \mathrm{OOO}-5, \mathrm{OOO}$ & DD & Stable ${ }^{a}$ & $\begin{array}{l}\text { Destruction of habitat }{ }^{b}, \\
\text { powerlines, pesticides }^{b}, \\
\text { pillaging of nests }\end{array}$ \\
\hline $\begin{array}{l}\text { Falco tinnunculus } \\
\text { dacotiae }\end{array}$ & $?$ & 400 & VU & Stable $^{a}$ & $\begin{array}{l}\text { Destruction of habitat }{ }^{b} \text {, } \\
\text { agricultural recession, } \\
\text { illegal hunting, } \\
\text { powerlines }\end{array}$ \\
\hline Falco eleonorae & 66 & 200 & NT & Increasing & $\begin{array}{l}\text { Human disturbance, } \\
\text { pesticides }^{b}\end{array}$ \\
\hline $\begin{array}{l}\text { Falco peregrinus } \\
\text { pelegrinoides }\end{array}$ & 7 & 75 & EN & Increasing & $\begin{array}{l}\text { Illegal hunting, pillaging } \\
\text { of nests, powerlines, } \\
\text { human disturbance }^{b}\end{array}$ \\
\hline Tyto alba gracilirostris & $?$ & 100 & EN & Decreasing $^{a}$ & $\begin{array}{l}\text { Agricultural recession, } \\
\text { road-kill, poisons }^{b}\end{array}$ \\
\hline Tyto alba alba & $?$ & $300-400$ & $\mathrm{NE}$ & Stable $^{a}$ & $\begin{array}{l}\text { Road-kill, poisons }^{b}, \\
\text { pillaging of nests }\end{array}$ \\
\hline Asio otus canariensis & $?$ & $>_{1,000}$ & DD & Stable $^{a}$ & Road-kill, poisons $^{b}$ \\
\hline
\end{tabular}

IUCN Red List categories: Critically Endangered (CR), Endangered (EN), Vulnerable (VU), Near Threatened (NT), Data Deficient (DD), Not Evaluate (NE).

${ }^{a}$ Estimate on the basis of scarce information.

${ }^{b}$ Probable threats. 
population, and a reduction of 68\% in three generations (1959-2001) has been estimated (Palacios unpublished data).

In the past, Egyptian Vulture was a common bird throughout the Canaries, considered the most numerous diurnal bird of prey in the Archipelago (Delgado 1999). The greatest concentrations were found on Gran Canaria and Tenerife, followed by Fuerteventura and Lanzarote, with fewer on La Gomera. It could have been present in the past on El Hierro and La Palma. Since the 1950 o rapid decline has been observed (Palacios 2000), and it was extinct in La Gomera around 1955. In the 1980s there were fewer than five individuals on Gran Canaria, which have now disappeared (Martín 1987). In Tenerife, the last chick known was born in 1979, while the last pair was seen in Teno Alto in 1985 (Delgado et al. 1988). The decomposing corpse of a third-year subadult was found in 1995 on a beach of Los Silos (Ramos 1996). The species is very occasionally seen on Gran Canaria, probably wandering or passage birds (Trujillo 1993, Martín and Lorenzo 2001). Limiting factors involved are largely unknown; it has been hypothesized that negative effects of industrialization, the development of tourism and modification of habitat, human population increase, reduction in livestock farming and use of pesticides were the main culprits. Moreover, a recent study on Fuerteventura suggested that the main causes of mortality were accidents with powerlines, illegal use of poisons and the ingestion of lead shot (Donázar et al. 2002b, Donázar 2003).

\section{Sparrowhawk Accipiter nisus granti}

Sparrowhawks are found on the central and western islands (Gran Canaria, Tenerife, La Gomera, La Palma and El Hierro), and on Madeira (Portugal). Early information affirming that Sparrowhawk bred in good numbers on Lanzarote and Fuerteventura (Bannerman 1963, Trotter 1970) is clearly erroneous, and probably referred to migrating birds (Martín 1987). It was recently discovered breeding in El Hierro (Delgado 1985).

Quilis et al. (1993) estimated a total population of $c$. 170 pairs in 1987/8: 75 on Tenerife, 25 on La Gomera, 50 on La Palma and 20 on El Hierro. It was considered almost extinct on Gran Canaria, but improvements in natural forest conservation and an increase in reforestation with pines may explain the recovery here, with breeding increasing in the 1990s (Rodríguez and Moreno 1995, Naranjo et al. 1999). Probably for similar reasons, the species seems to have increased on other islands. In Tenerife, it has begun to nest in apparently marginal habitats such as avocado plantations in deforested areas (Trujillo and Barone 1998), and has frequently been observed in built-up areas such as La Laguna or Santa Cruz de Tenerife (Martín and Lorenzo 2001). The current population has been estimated at over 100 pairs (Rubén Barone pers. comm.). Habitat destruction and illegal hunting seem to be the principal threats (Martín et al. 1990, Carrillo and Delgado 1991).

\section{Canarian Buzzard Buteo buteo insularum}

Canarian Buzzard was initially present on all the islands, but became extinct on Lanzarote towards the end of the 1960s (Trotter 1970). Polatzek (1908) 
distinguished the buzzards of the eastern islands as belonging to a different subspecies, B. b. lanzaroteae, but this differentiation was not accepted (Bannerman 1963). In the western islands it shows a clear preference for forested areas, although it can be found in a wide variety of habitats, especially along the edges of pine and laurisilva forests, gullies, inland crags and even coastal cliffs (Martín 1987).

Quilis et al. (1993) estimated a total population of c. 425-450 pairs in 1988: 15-20 pairs in Fuerteventura, 115 in Gran Canaria, 170-180 in Tenerife, 60 in La Gomera, 45 in La Palma and 20-30 in El Hierro. This is in spite of the negative effect of powerlines, poisons, nest-robbing and illegal hunting, which undoubtedly lead to a high mortality rate (Palacios unpublished data). The species has recently shown a recovery on some islands, possible due to the greater degree of protection afforded to natural areas in recent years, an increase in forested land and greater public awareness. The best-documented case has been that of Fuerteventura, where the species was on the brink of extinction in the 1970s (scarcely 5-7 pairs according to Emmerson 1983). In 1988 the population there was calculated at $15-20$ pairs and there are currently more than $85-90$ pairs (Palacios unpublished data). In Tenerife, the population shows signs of saturation (Rubén Barone pers. comm.). Buzzards are blamed for losses to cattle, rabbit and Barbary Partridge stock, and are subject to illegal hunting and poisoning (Martín et al. 1990, Carrillo and Delgado 1991, Martín and Lorenzo 2001).

\section{Osprey Pandion haliaetus}

Ospreys were once found on all the Canary Islands, with an estimated population of 80 pairs at the beginning of the twentieth century and 60 pairs in the 1950s (González et al. 1992). From the 1970s to the end of the century, the population began to fall until the bird disappeared from Gran Canaria, La Palma and Fuerteventura, apparently as a result of intense changes in the coast caused by the fast-growing tourism and fishing industries.

Five regional censuses have been carried out recently, with 10-13 pairs recorded in 1983 (Díaz et al. 1986), 12-14 in 1984 (Hernández et al. 1987), 12 in 1987 (Delgado et al. 1988), 10-13 in 1991 (González et al. 1992) and 16-22 in 2000 (Martín and Lorenzo 2001). According to this last study, 4 pairs were on Alegranza, 1 or 2 on Montaña Clara, 1 or 2 on Lanzarote, 3 or 4 on Tenerife, 3-5 on La Gomera and 4 or 5 on El Hierro. A pair settled on the islet of Lobos in 1999, but has failed to produce young, probably because of constant disturbance by both tourists and fishermen (Palacios unpublished data). This is the largest population in Spanish territory, as Osprey is extinct on the mainland and only 15-17 pairs were recorded in the Balearics in 2001 (Triay and Siverio 2003).

\section{Western Canary Kestrel Falco tinnunculus canariensis}

Western Canary Kestrel is found on central and western islands: Gran Canaria, Tenerife, La Gomera, La Palma and El Hierro; and is also present on Madeira and the Salvages (Martín 1987). Kestrel is the most abundant and most widespread bird of prey on the Canaries, with an estimated regional population of between 5,000 and 6,000 pairs (Tucker and Heath 1990, Aparicio 1997), most of 
which belong to the subspecies canariensis. In Tenerife in 1984, the population was estimated at 1,100 pairs (Martín 1987). Population density ranges from 0.54 birds / km on La Gomera, to 0.45 on La Palma, 0.38 on Gran Canaria, 0.36 on El Hierro and 0.23 on Tenerife (Carrillo and Delgado 1996).

Despite its abundance, information on demographic trends of this subspecies in the Canaries is lacking, although the population appears to be stable (Martín and Lorenzo 2001). The principal threats seem to be habitat modification, illegal hunting, pillaging of nests, collisions with powerlines and pesticide poisoning.

\section{Eastern Canary Kestrel Falco tinnunculus dacotiae}

Eastern Canary Kestrel is the most common bird of prey on Lanzarote and Fuerteventura (especially the former), where it occupies almost all regions, from the Punta de Jandía to the National Park of Timanfaya. Lanzarote has between 150 and 200 nesting pairs (Concepción 1992), and there are another 10-15 pairs on the smaller islands: 4-6 pairs on Alegranza, 1 or 2 on Montaña Clara, 4 or 5 on La Graciosa and 1 or 2 on Lobos (Carrillo and Delgado 1996, Martín and Lorenzo 2001). The subspecies found in the eastern islands has a somewhat lower population density than that in the western islands: 0.09 birds $/ \mathrm{km}$ on Lanzarote and 0.05 on Fuerteventura. The aridity, lower productivity and lower area of cultivation of the region it occupies are the probable reasons for these differences (Carrillo and Delgado 1996).

The populations seem to be stable, since an expansion of gardens in residential areas may have balanced the loss of agricultural land in the last few years. Eastern Canary Kestrel nests in inland crags, gullies, craters, quarries and coastal cliffs, as well as in buildings and palm trees. Reduction of food resources due to abandonment of agriculture and urban expansion, illegal hunting and collisions with powerlines are the principal threats (Palacios unpublished data).

\section{Eleanora's Falcon Falco eleonorae}

The distribution of Eleonora's Falcon on the Canary Islands is limited to the islets of the Chinijo Archipelago, near northern Lanzarote. Old references refer to Fuerteventura as a breeding site. Meade-Waldo discovered a nest with three eggs of this species on cliffs close to Gran Tarajal (perhaps La Entallada) in July 1889 (Bannerman 1963). Hooker (1958) found a pair, probably of this species, in the same area. Individual birds are still seen on the island, but must be considered wandering birds. On Lanzarote there have been continuous records in the Riscos de Famara, although breeding has never been proved (Martín and Lorenzo 2001). On La Graciosa there are references to the species nesting at the beginning of the 1960s (Etchecopar and Hue 1960), perhaps on Montaña Amarilla, where a single pair nested a few years later (Lovegrove 1971).

According to the last published census in 2000, the population in the Canary colonies was 183-199 pairs (Martín and Lorenzo 2001): Alegranza 59 pairs, Montaña Clara 85-100 pairs, Roque del Este 37 pairs and Roque del Oeste 2 or 3 pairs. This represents an increase since 1987 and 1983, when a total of 66 pairs was recorded (Trujillo et al. 1994, Hernández et al. 1985). Although due mainly to better coverage, this increase probably also represents a real increase in the 
population (Rodríguez 2000). Legal protection of all nesting sites within the Archipiélago Chinijo Natural Park and the Integral Nature Reserve of Islotes seems to have put an end to the supposed major threats: army manoeuvres and nest-pillaging (Carrillo and Delgado 1991). However, the birds still suffer some human disturbances of nesting areas.

\section{Barbary Falcon Falco peregrinus pelegrinoides}

A detailed study is needed to clarify the taxonomic situation of Barbary Falcon in the Canary Islands. Following the criteria of Vaurie (1965) it has been considered a full species Falco pelegrinoides, but the latest review of the genus maintains it as a subspecies of Falco peregrinus (Del Hoyo et al. 1994) and indeed the first genetic studies seem to confirm this (Amengual et al. 1996).

This species almost became extinct in the Canaries, and was considered to be the rarest and most endangered bird of prey in Spain (Delgado et al. 1990), and consequently in the European Union. This was the conclusion of initial research which located a maximum population of seven pairs (Hernández et al. 1991). In 1991 two pairs were located in Tenerife, where breeding had never been confirmed (Hernández et al. 1992). In 1994 adult birds were observed in La Palma (Trujillo 1995, 1996). A study carried out in the late 1990s (Delgado et al. 1999) described the recovery of the species, with an estimated minimum of 48-52 pairs distributed as follows: Roque del Este 1 pair; Alegranza 2 pairs; Montaña Clara 1 pair; Lanzarote 9 pairs; Fuerteventura 4 pairs; Gran Canaria 10 pairs; Tenerife 11 pairs; La Gomera 7 pairs; El Hierro 2 or 3 pairs; La Palma 5 or 6 pairs. More recently, 76-81 pairs have been recorded, with the largest increases on La Gomera (12-14), Tenerife (15), Gran Canaria (15) and La Palma (8-10) (Siverio and Concepción 2003). In Fuerteventura, an adult bird was illegally captured in 2001 by falconers, and another was hunted (Palacios unpublished data). A minimum of six birds died in collisions with powerlines in Lanzarote and Gran Canaria, and tourism and various outdoor sports cause serious disturbance to nesting pairs (Siverio and Concepción 2003).

\section{Canary Barn Owl Tyto alba gracilirostris}

The endemic Canary Barn Owl is restricted to the eastern Canary Islands: Lanzarote, Fuerteventura and the Chinijo Archipelago. Little information is available, with the sole detailed work examining only distribution (Delgado et al. 1992) and providing no population estimate. The bird has disappeared from the islet of Lobos, where the only data are of one supposed nesting site found in 1987. A small population of 3 or 4 pairs remains on Alegranza, 3 pairs on La Graciosa and 1 pair on Montaña Clara (Martín and Lorenzo 2001). Higher numbers were estimated for Lanzarote (50-100 pairs; Concepción 1992), but the population here seems to have decreased by half in the last few years (Martín and Lorenzo 2001). A similar pattern has occurred in Fuerteventura, where the bird was never abundant but has disappeared in recent years from some areas where it used to be common. It does not breed on the peninsula of Jandía, and the total island population is less than 30 pairs (Palacios unpublished data). 
The strong recession in agriculture in recent decades (only $0.14 \%$ of Fuerteventura is now cultivated) has seriously reduced the population of Mus domesticus, the Canary Barn Owl's principal food (Concepción 1992, Palacios unpublished data). Román (1997) hypothesized that road-kill, nest-robbing and illegal hunting may result in high mortality rates in this endemic subspecies. Although nest-robbing seems not to be so important (pers. obs.), the use of anticoagulant poison for rat control, a common practice in some areas, should be examined.

\section{Barn Owl Tyto alba alba}

The nominate subspecies, with a European range which includes the British Isles, has been identified as the subspecies occupying the western and central islands of the Canary Archipelago: Gran Canaria, Tenerife, La Gomera, El Hierro and La Palma (Cramp 1985). As T. a. detorta is described for Cape Verde archipelago and T. a. schmitzi for Madeira, the presence in the Canaries of the nominate race means a detailed study of morphology, biometrics and genetics is needed to clarify its taxonomic situation, given its geographical isolation and ecological peculiarities.

Information on the bird's status and trends is scarce, with the exception of the islands of Tenerife and La Gomera, where censuses have been carried out. A population of about 250 pairs is estimated for Tenerife (Siverio 1997), whilst only about 15 pairs have been proposed for La Gomera (Siverio et al. 1999). The first evidence of nesting was obtained for Gran Canaria in 1987 (Trujillo 1989). In that year, Delgado et al. (1988) found the species in only five localities. Other authors have pointed out that the population was probably once greater although always much less common than on Tenerife.

For the rest of the western islands information is very scarce: there are a few records on El Hierro (Delgado et al. 1988, Martín and Machado 1985, Martín and Lorenzo 2001) and La Palma (Trujillo and Rebolé 1989, Concepción 1992, Martín and Lorenzo 2001). Thus, with the exception of Tenerife, Tyto alba alba should be considered a rare species in the Canaries, probably seriously menaced in some islands. Habitat modification and destruction, nest-robbing and road-kill are the principal threats (Martín et al. 1990).

\section{Long-eared Owl Asio otus canariensis}

The endemic subspecies of Long-eared Owl seems to be abundant and widely distributed on all the western and central islands (Gran Canaria, Tenerife, La Gomera, El Hierro and La Palma), although detailed data on distribution and biology in Tenerife and La Palma are scarce (Martín 1987, Barone et al. 1994, Delgado et al. 1988).

The bird is absent from arid regions although in southern Tenerife and Gran Canaria it occupies similar habitats. In winter 2000 it was reported in Fuerteventura for the first time, with three individuals singing and making display flights in a pine wood at Betancuria (Palacios 1999, E. García del Rey pers. comm.). These birds may have been migrants of the nominate subspecies rather than from other islands, where they are apparently sedentary. Individuals in apparent 
migration have been reported elsewhere, such as the islet of Alegranza (Martín and Lorenzo 2001, Trujillo and Siverio 2001). Road-kill is the principal threat (Martín et al. 1990) but, as with Barn Owl, rat poisons may be a major factor.

\section{Discussion}

The prospects of Canarian raptor conservation are generally hopeful, after a century of changes and rapid economic and urban development that caused some extinctions and severe pressure on habitats. In the last decade, the effectiveness of the protected area network in the Canaries (40.4\% of the territory is protected), along with a greater awareness on the part of the general public and larger investment by the authorities in environmental projects, is bearing fruit for the conservation of birds of prey. Thus, Barbary Falcon Falco peregrinus pelegrinoides has recolonized all islands, increasing its population spectacularly. In contrast, Egyptian Vulture Neophron percnopterus majorensis continues to be the most endangered Canarian raptor.

Despite this general recovery, the prospects for Canarian birds of prey are still very delicate: four are listed as Critically Endangered or Endangered in the new Red List of Birds of Spain, and only one is out of danger (Table 1). Due to their uniqueness and limited distribution, it would be advisable to start conservation plans for each one of these species and subspecies. The most urgent problems to solve are deaths resulting from collisions with powerlines and the illegal use of poisons. It is also advisable to carry out periodic censuses on every island and to increase efforts in environmental education of young people. However, given that the current taxonomy and phylogeny of the birds of the Canary islands has its origins in works from the nineteenth century or early twentieth century, in which only skins were studied, and in the light of new genetic techniques, it would be wise to review all the island populations. Their uniqueness with respect to the populations of mainland Spain and of North Africa may be much more marked than is initially believed (e.g. Donázar et al. 2002a).

\section{Acknowledgements}

I am very grateful to José Antonio Donázar and Rubén Barone for their review of the manuscript and valuable comments. Special thanks go to Tim Robinson and Paul Short for their help with the English translation.

\section{References}

Amengual, J., Heidrich, P., Wink, M. and Rodríguez, F. (1996) El complejo Falco peregrinus/ F. pelegrinoides en Fuerteventura, Islas Canarias: nuevos datos derivados de la secuencia de gen mitocondrial cytb. XIII Jornadas Ornitológicas Españolas. Figueres (Girona).

Aparicio, J. M. (1997) Cernícalo vulgar Falco tinnunculus. Pp. 130-131 in F.J. Purroy, coord. Atlas de las aves de España (1975-1995). Barcelona: Lynx Edicions.

Bannerman, D. A. (1963) Birds of the Atlantic Islands. Vol. I. A history of the birds of the Canary Islands and of the Salvages. Edinburgh and London: Oliver and Boyd.

Barone, R., Siverio, F. and Trujillo, D. (1994) Sobre la distribución y el hábitat del Búho Chico Asio otus canariensis (Madarasz, 1901) en la isla de La Palma, Canarias (Aves: Strigidae). Rev. Acad. Canar. Cienc. 6: 65-75. 
Carrillo, J. and Delgado, G. (1991) Threats to and conservationist aspects of birds of prey in the Canary Islands. Birds Prey Bull. 4: 25-32.

Carrillo, J. and Delgado, G. (1996) Patrones de distribución y abundancia relativa de Falco tinnunculus dacotiae (Hartert, 1913) en las Islas Canarias. Pp. 471-476 in J. Muntaner and J. Mayol, eds. Biología y conservación de las rapaces mediterráneas, 1994. Madrid: SEO/BirdLife.

Concepción, D. (1992) Avifauna del Parque Nacional de Timanfaya. Madrid: ICONA.

Cramp, S. (ed.) (1985) The Birds of the Western Palearctic. Vol. IV. Oxford and New York: Oxford University Press.

Delgado, G. (1985) Presencia y nidificación del gavilán (Accipiter nisus granti Sharpe, 1890) en la isla de El Hierro. Doñana, Acta Vertebrata 12: 172-173.

Delgado, G. (1999) Guirre. P. 1814 in Gran Enciclopedia Canaria, VII. Santa Cruz de Tenerife: Ediciones Canarias.

Delgado, G., Trujillo, N., Carrillo, J., Santana, F., Quilis, V., Nogales, M., Trujillo, O., Emmerson, K. and Hernández, E. (1988) Censo de las aves rapaces del Archipiélago Canario. Museo de Ciencias Naturales de Santa Cruz de Tenerife. Unpublished report.

Delgado, G., Carrillo, J., Nogales, M., Quilis, V. and Trujillo, O. (1990) Aves rapaces de Canarias. La Garcilla 79: 10-13.

Delgado, G., Carrillo, J. and Trujillo, D. (1992) Sobre la presencia y distribución de la Lechuza Común (Tyto alba) (Scopoli, 1769) en las islas orientales del Archipiélago Canario. Vieraea 21: 145-148.

Delgado, G., Concepción, D., Siverio, M., Hernández, E., Quilis, V. and Trujillo, D. (1999) Datos sobre la distribución y biología del Halcón de Berbería (Falco peregrinus pelegrinoides) en las Islas Canarias (Aves: Falconidae). Vieraea 27: 287-298.

Del Hoyo, J., Elliot, A. and Sargatal, J. (eds.) (1994) Handbook of the birds of the world. Vol. 2. New World vultures to guineafowl. Barcelona: Lynx Edicions.

Díaz, G., Trujillo, O. and Hernández, E. (1986) Situación del águila pescadora (Pandion haliaetus) en Canarias. Boletín de la Estación Central de Ecología 29: 67-72.

Donázar, J. A. (2003) Alimoche Común, Neophron percnopterus. In R. Martí and J. C. Del Moral, eds. Atlas de las aves nidificantes de España. Madrid: Ministerio de Medio Ambiente-SEO/BirdLife.

Donázar, J. A., Negro, J. J., Palacios, C. J., Gangoso, L., Godoy, J. A., Ceballos, O. and Hiraldo, F. (2002a) Description of a new subspecies of the Egyptian Vulture (Accipitridae: Neophron percnopterus) from the Canary Islands. J. Raptor Res. 36: 17-23.

Donázar, J. A., Palacios, C. J., Gangoso, L., Ceballos, O., González, M. J. and Hiraldo, F. (2002b) Conservation status and limiting factors of the endangered population of Egyptian Vulture (Neophron percnopterus) in the Canary Islands. Biol. Conserv. 107: 89-97.

Emmerson, K. W. (1983) Actual and potential threats to the Canary Houbara. Bustard Stud. 1: $51-56$.

Etchecopar, R. D. and Hue, F. (1960) Evolution récente de l'avifaune des Canarias. Pp. 193-196 in Proc. XII. Int. Orn. Congr. Helsinki.

Fernández-Palacios, J. M. and Días, E. (2001) Marco biogeográfico macaronésico. Pp. 45-52 in J. M. Fernández-Palacios and J. L. Martín Esquivel, eds. Naturaleza de las Islas Canarias. Ecología y Conservación. Madrid: Publicaciones Turquesa.

González, G., Santiago, J. M. and Fernández, L. (1992) El águila pescadora (Pandion haliaetus) en España. Censo, reproducción y conservación. Madrid: ICONA.

Hernández, E., Martín, A., Díaz, G., Trujillo, O. and Ascanio, M. (1985) Censo y datos sobre la biología del Halcón de Eleonora (Falco eleonorae Gené, 1839) en las Islas Canarias. Agosto-septiembre 1983. Doñana Acta Vertebrata 12: 63-73.

Hernández, E., Díaz, G. and Trujillo, O. (1987) El águila pescadora (Pandion haliaetus) en Canarias: situación actual y aspectos de la biología. Vieraea 17: 203-207. 
Hernández, E., Delgado, G., Carrillo, J., Nogales, M. and Quilis, V. (1991) A preliminary census and notes on the distribution of the Barbary Falcon (Falco pelegrinoides Temminck, 1829) in the Canary Islands. Bonn. Zool. Beitr. 42: 27-34.

Hernández, E., Delgado, G. and Quilis, V. (1992) El Halcón de Berbería (Falco pelegrinoides Temminck, 1829), nueva especie nidificante en Tenerife (I. Canarias). Vieraea 21: 170.

Hooker, T. (1958) Birds seen on the Eastern Canary Islands of Fuerteventura. Ibis 100: 446-449.

Lovegrove, R. (1971) BOU supported expedition to Northeast Canary Islands. Ibis 113: 269-272.

Martín, A. (1987) Atlas de las aves nidificantes en la isla de Tenerife. Santa Cruz de Tenerife: Instituto de Estudios Canarios.

Martín, A. and Lorenzo, J. A. (2001) Aves del archipiélago canario. La Laguna: Francisco Lemus.

Martín, A. and Machado, A. (1985) Nidificación de la Lechuza común (Tyto alba) en la isla de El Hierro y datos sobre su alimentación. Vieraea 15: 43-46.

Martín, A., Hernández, E., Nogales, M., Quilis, V., Trujillo, O. and Delgado, G. (1990) Libro Rojo de los vertebrados terrestres de Canarias. Santa Cruz de Tenerife: Caja General de Ahorros de Canarias.

Naranjo, J., Velázquez, P., Negrín, F. and Arencibia, G. (1999) Los tratamientos selvícolas y el gavilán en Gran Canaria. Medio Ambiente Canarias 14: 16-18.

Palacios, C. J. (1999) Búho chico (Asio otus). Noticiario ornitológico. Ardeola 46: 16o.

Palacios, C. J. (2000) Decline of the Egyptian Vulture (Neophron percnopterus) in the Canary Islands. J. Raptor Res. 34: 61.

Polatzek (1908) Die Vögel der Kanaren. Orn. Jahrb. 19: 161-197.

Quilis, V., Delgado, G., Carrillo, J., Nogales, M. and Trujillo, O. (1993) Status y distribución del ratonero común (Buteo buteo L.) y el gavilán (Accipiter nisus L.) en las Islas Canarias. Vieraea 22: 89-96.

Ramos, J. J. (1996) Alimoche común Neophron percnopterus. Noticiario ornitológico. Ardeola 43: 246.

Rodríguez, F. (2000) Anillamientos y recuperaciones de Halcón de Eleonora Falco eleonora en Canarias. Rev. Anillamiento 6: 24-27.

Rodríguez, F. and Moreno, A.C. (1995) Nidificación del gavilán (Accipiter nisus granti Sharpe, 1890) en la isla de Gran Canaria (Aves, Accipitridae). Vieraea 24: 193-194.

Román, J. (1997) Lechuza común Tyto alba. Pp. 254-255 in F. J. Purroy, coord. Atlas de las aves de España (1975-1995). Barcelona: Lynx Edicions.

Siverio, F. (1997) Distribución estatus de Tyto alba (Scopoli, 1769) en Tenerife, Islas Canarias (Aves, Tytonidae). Vieraea 26: 121-131.

Siverio, M. and Concepción, D. (2003). Halcón Tagarote Falco pelegrinoides. In R. Martí and J. C. Del Moral, eds. Atlas de las aves reproductoras en España. Madrid: Ministerio de Medio Ambiente-SEO/BirdLife.

Siverio, F., Barone, R., Siverio, M., Trujillo, D. and Ramos, J. J. (1999) Response to conspecific playback calls, distribution and habitat of Tyto alba (Aves, Tytonidae) on La Gomera, Canary Islands. Rev. Acad. Canar. Cienc. 11: 213-222.

Triay, R. and Siverio, M. (2003) Águila Pescadora Pandion haliaetus. In R. Martí and J. C. Del Moral, eds. Atlas de las aves nidificantes de España. Madrid: Ministerio de Medio Ambiente-SEO/BirdLife.

Trotter, W. D. C. (1970) Observations faunistiques sur l'Île de Lanzarote (Canaries). L'Oiseau 40: 160-172.

Trujillo, D. (1989) Lechuza común (Tyto alba). Noticiario ornitológico. Ardeola 36: 255.

Trujillo, O. (1993) Situación de la avifauna de Gran Canaria: problemática conservacionista. Bol. Mus. Mun. Funchal 2: 297-315. 
Trujillo, D. (1995) Halcón de Berbería (Falco pelegrinoides). Noticiario ornitológico. Ardeola 42: 219.

Trujillo, D. (1996) Halcón Peregrino (Falco peregrinus). Noticiario ornitológico. Ardeola 43: 247.

Trujillo, D. and Barone, R. (1998) Nidification de l'Épervier d'Europe (Accipiter nisus) dans des cultures d'avocats (Îles Canaries). Alauda 66: 69.

Trujillo, D. and Rebolé, A. (1989) Lechuza común (Tyto alba). Noticiario ornitológico. Ardeola 36: 255.

Trujillo, D. and Siverio, F. (2001) Búho Chico (Asio otus). Noticiario ornitológico. Ardeola 48: 145 .

Trujillo, O., Carrillo, J., Nogales, M. and Quilis, V. (1994) Distribución y status del halcón de Eleonor (Falco eleonorae) en las Islas Canarias. Vieraea 23: 149-153.

Tucker, G. M. and Heath, M. F. (eds.) (1990) Birds in Europe: their conservation status. Cambridge, U.K.: BirdLife International.

Vaurie, C. (1965) The birds of the Palearctic Fauna. A systematic reference: Non Passeriformes. London: Witherby.

\section{CÉSAR-JAVIER PALACIOS*}

Department of Applied Biology, Estación Biológica de Doñana (CSIC), Avenida María Luisa s/n, Pabellón del Perú, 41013 Seville, Spain. E-mail: cjpalacios@wanadoo.es

${ }^{*}$ Corresponding author.

Received 16 December 2002; revision accepted 10 March 2004 